Behind Spanish American Footlights 
THIS PAGE INTENTIONALLY LEFT BLANK 


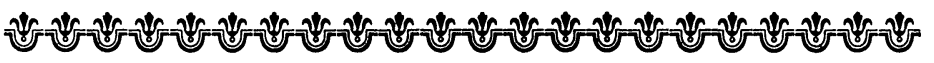

\title{
Behind Spanish American Footlights
}

\author{
by WILLIS KNAPP JONES
}

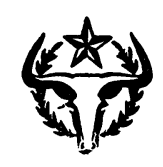

University of Texas Press . Austin . London 
Library of Congress Catalog Card No. 65-11145

Copyright (C) 1966 by Willis Knapp Jones All Rights Reserved

Published with the assistance of a grant from the Ford Foundation

under its program for the support of publications in the humanities and social sciences and

with a grant from Miami University, Oxford, Ohio Manufactured in the United States of America by the Printing Division of the University of Texas, Austin Bound by Universal Bookbindery, Inc., San Antonio 
Dedicated to

JOHN D. MILLETT

President of Miami University 1953-1964

Not only did he give assistance by arranging reduced teaching loads and by grants, but he also evidenced a time-consuming personal interest in this research project 
THIS PAGE INTENTIONALLY LEFT BLANK 